Revue bibliographique pour le domaine irano-aryen

\title{
Behzad Mofidi-Nasrabadi. „Bilder der Macht. Zur Programmatik der achämenidischen Palastkunst in der Zeit Dareios I"
}

\section{Astrid Nunn}

\author{
(2) OpenEdition \\ Journals \\ Édition électronique \\ URL : http://journals.openedition.org/abstractairanica/44190 \\ DOI : 10.4000/abstractairanica.44190 \\ ISBN : 1961-960X \\ ISSN : 1961-960X \\ Éditeur : \\ CNRS (UMR 7528 Mondes iraniens et indiens), Éditions de l'IFRI
}

\section{Référence électronique}

Astrid Nunn, « Behzad Mofidi-Nasrabadi. „Bilder der Macht. Zur Programmatik der achämenidischen Palastkunst in der Zeit Dareios I" », Abstracta Iranica [En ligne], Volume 37-38-39 | 2018, document 28, mis en ligne le 30 décembre 2018, consulté le 26 septembre 2020. URL : http://

journals.openedition.org/abstractairanica/44190; DOI : https://doi.org/10.4000/abstractairanica. 44190

Ce document a été généré automatiquement le 26 septembre 2020.

Tous droits réservés 


\title{
Behzad Mofidi-Nasrabadi. „Bilder der Macht. Zur Programmatik der achämenidischen Palastkunst in der Zeit Dareios I"
}

\author{
Astrid Nunn
}

\section{RÉFÉRENCE}

Behzad Mofidi-Nasrabadi. „Bilder der Macht. Zur Programmatik der achämenidischen Palastkunst in der Zeit Dareios I." in Karin Stella Schmidt (ed.). Gedenkschrift für Mark A. Brandes (1929-2011). 2015, p. 149-177. (AOAT 423)

1 L'idéologie impériale des Rois achéménides se manifeste dans l'art aulique plus en allusions qu'en thèmes explicatifs. Certains thèmes ont été repris de la tradition mésopotamienne, ceux qui ne l'ont pas été, indiquent ainsi une volonté active. Il en résulte une grammaire et une langue iconographique simples et ainsi compréhensibles par tous les peuples soumis. L'architecture a créé un espace mythique dans lequel habite le «roi-dieu». En image le roi égale dieu ce qui, selon l'A., revient à une forme subtile de divinisation (Vergöttlichung) telle que nous la connaissons de Sargon d'Agadé. 


\section{AUTEURS}

\section{ASTRID NUNN}

Université de Munich 